\title{
2009s-11 \\ What Does it Take for an R\&D Tax Incentive Policy to be Effective?
}

\author{
Pierre Mohnen, Boris Lokshin
}

\begin{tabular}{c}
\hline Série Scientifique \\
Scientific Series
\end{tabular}

\section{Montréal \\ Avril 2009}

(c) 2009 Pierre Mohnen, Boris Lokshin. Tous droits réservés. All rights reserved. Reproduction partielle permise avec citation du document source, incluant la notice (C).

Short sections may be quoted without explicit permission, if full credit, including $\left({ }^{\circ}\right.$ notice, is given to the source.
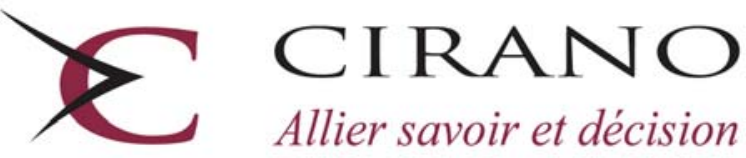

Allier savoir et décision

Centre interuniversitaire de recherche en analyse des organisations 


\section{CIRANO}

Le CIRANO est un organisme sans but lucratif constitué en vertu de la Loi des compagnies du Québec. Le financement de son infrastructure et de ses activités de recherche provient des cotisations de ses organisations-membres, d'une subvention d’infrastructure du Ministère du Développement économique et régional et de la Recherche, de même que des subventions et mandats obtenus par ses équipes de recherche.

CIRANO is a private non-profit organization incorporated under the Québec Companies Act. Its infrastructure and research activities are funded through fees paid by member organizations, an infrastructure grant from the Ministère du Développement économique et régional et de la Recherche, and grants and research mandates obtained by its research teams.

\section{Les partenaires du CIRANO}

\section{Partenaire majeur}

Ministère du Développement économique, de l’Innovation et de l’Exportation

\section{Partenaires corporatifs}

Banque de développement du Canada

Banque du Canada

Banque Laurentienne du Canada

Banque Nationale du Canada

Banque Royale du Canada

Banque Scotia

Bell Canada

BMO Groupe financier

Caisse de dépôt et placement du Québec

DMR

Fédération des caisses Desjardins du Québec

Gaz de France

Gaz Métro

Hydro-Québec

Industrie Canada

Investissements PSP

Ministère des Finances du Québec

Power Corporation du Canada

Raymond Chabot Grant Thornton

Rio Tinto Alcan

State Street Global Advisors

Transat A.T.

Ville de Montréal

\section{Partenaires universitaires}

École Polytechnique de Montréal

HEC Montréal

McGill University

Université Concordia

Université de Montréal

Université de Sherbrooke

Université du Québec

Université du Québec à Montréal

Université Laval

Le CIRANO collabore avec de nombreux centres et chaires de recherche universitaires dont on peut consulter la liste sur son site web.

Les cahiers de la série scientifique (CS) visent à rendre accessibles des résultats de recherche effectuée au CIRANO afin de susciter échanges et commentaires. Ces cahiers sont écrits dans le style des publications scientifiques. Les idées et les opinions émises sont sous l'unique responsabilité des auteurs et ne représentent pas nécessairement les positions du CIRANO ou de ses partenaires.

This paper presents research carried out at CIRANO and aims at encouraging discussion and comment. The observations and viewpoints expressed are the sole responsibility of the authors. They do not necessarily represent positions of CIRANO or its partners. 


\title{
What Does it Take for an R\&D Tax Incentive Policy to Be Effective? ${ }^{*}$
}

\author{
Pierre Mohnen ${ }^{\dagger}$, Boris Lokshin ${ }^{\ddagger}$
}

\begin{abstract}
Résumé
Alors qu'en 1996, 12 pays de l'OECD offraient des crédits d'impôt recherche, en 2008 ils furent au nombre de 21. La plupart des pays optent pour des crédits d'impôt en volume et non en accroissement. Nous jetons un regard critique sur la façon dont l'efficacité des incitations à la R-D a été évaluée jusqu'ici. Que ce soit sur la base de modèles structurels qui estiment une élasticité-prix à la recherche ou à partir de méthodes d'évaluation de traitement, la plupart des études testent l'existence d'un effet d'additionalité. Si les entreprises font plus qu'un dollar de recherche par dollar de crédit d'impôt, la politique est considérée comme efficace. Une analyse coût-bénéfice plus globale qui inclurait également les coûts de gestion publique et privée des crédits d'impôt, les coûts additionnels dus à la taxation, les externalités de la recherche et les effets de celle-ci sur l'innovation et la productivité, serait plus appropriée.

Le bénéfice social net qui ressort d'une telle analyse est sensible à des estimations par ailleurs assez imprécises de certains de ces effets. Nous montrons que la perte sèche liée aux crédits d'impôt recherche en volume dépend du niveau de R-D exécutée avant l'entrée en vigueur des crédits d'impôt. Nous examinons l'efficacité de la politique des crédits d'impôt recherche aux Pays-Bas. Nous montrons notamment que des changements marginaux dans certains paramètres de cette politique n’ont qu'un impact limité sur les dépenses privées de recherche des entreprises. Cette politique est plus efficace pour les petites entreprises que pour les grandes. Nous terminons en pesant le pour et le contre d'une politique de crédits d'impôt en volume comparée à une politique en accroissement.
\end{abstract}

Mots clés : crédits d’impôt recherche; évaluation de politiques; analyse coûtbénéfice.

\footnotetext{
* A first version of the paper was presented at the CESifo Venice Summer Institute 2008 workshop on "Reforming Rules and Regulations - Laws, Institutions and Implementation". CESifo sponsorship to the Summer Institute 2008 is gratefully acknowledged. Part of this paper was also presented at the Expert Group Seminar "In Search of Good Practices in Evaluating R\&D Tax Incentives” as part of a contribution to an Expert Group on R\&D Tax Incentives Evaluation for the Research Directorate General of the European Commission. We thank the participants of both events for their critical remarks and in particular Bruno van Pottelsberghe, Jacques Mairesse and Vivek Ghosal for their valuable comments. We also wish to thank the anonymous referee for his incisive remarks. We acknowledge financial support from the SCIFI-GLOW grant no. 217436 of the $7^{\text {th }}$ EU Framework Program. This paper also appeared as UNU-MERIT working paper 2009-014.

${ }^{\dagger}$ University of Maastricht, UNU-MERIT and CIRANO, P.O. Box 616, 6200 MD, Maastricht, The Netherlands, p.mohnen@merit.unimaas.nl, (Corresponding author: Tel +31-43-388 4464, fax +31-43-388 4905).

† University of Maastricht and UNU-MERIT, P.O. Box 616, 6200 MD, Maastricht, The Netherlands, b.lokshin@os.unimaas.nl.
} 


\begin{abstract}
While in 1996, 12 OECD countries offered R\&D tax incentives, in 2008 this number increased to 21. Most countries have opted for level-based instead of incremental R\&D tax incentives. This paper takes a critical look at how the effectiveness of $R \& D$ tax incentives has been assessed in recent evaluations. Whether based on structural models estimating a price elasticity of $R \& D$ or on treatment evaluation methods, most studies estimate the cost effectiveness ratio or additionality. If the cost effectiveness ratio is greater than 1, or firms do more $R \& D$ than before, the policy is considered to be effective. A more proper net welfare evaluation of this policy should also include administration, compliance and transfer costs, the marginal burden of taxation, as well $R \& D$ externalities and the indirect effects on innovation and productivity.

The net welfare gain is shown to be sensitive to a certain number of parameters that are not always estimated with great precision. In particular, the transfer cost or deadweight loss associated with level-based tax incentives is shown to depend on the size of the firm, or more precisely its ex-ante $R \& D$ level. We report on the success of a past policy changes in the Netherlands and simulate the effect of various parameter changes in the existing Dutch $R \& D$ tax incentive scheme. We show that introducing marginal changes in the schemes's parameters has little impact of increased $R \& D$ spending. The policy is more effective for small firms than for large firms. We end with a discussion of the pros and cons of level-based versus incremental $R \& D$ tax incentives.
\end{abstract}

Keywords: $R \& D$ tax credits; policy evaluation; cost-benefit analysis

Codes JEL : O32, O38, H25, H50 


\section{Introduction}

Because of the conviction that $R \& D$ (research and development) earns a high social rate of return, contributes to economic growth or assures competitiveness, governments spend a non negligible amount of money to induce firms to invest in R\&D. A popular measure in this regards is the policy of $R \& D$ tax incentives. It reduces the corporate income taxes or the employer's social security contributions in proportion to the R\&D effort and thereby decreases the cost of doing R\&D so that firms move closer to the R\&D level that would be socially optimal. This policy has the virtue of being neutral, i.e. giving a tax relief to any kind of $R \& D$ expenditure, although some governments give special credits to for instance environmental $R \& D$ or $R \& D$ done in collaboration with universities.

The policy of R\&D tax incentives has been in place for many years in countries like the U.S., France or Canada. It was adopted in the UK a few years ago and is presently being considered to be introduced in Germany. While in 1996, 12 OECD countries offered R\&D tax incentives, in 2008 this number increased to 21. France, Canada, Norway, Australia and the Netherlands re-evaluate the usefulness and the effectiveness of their $R \& D$ tax incentives on a regular basis, because of its ever increasing importance in the science and technology budget. France and Spain recently reformed their policy of R\&D tax credits.

This paper has two objectives. The first is to review how the effectiveness of R\&D tax incentives has been assessed in previous evaluations, trying in this way to build up a comprehensive evaluation scheme, which would encompass previous evaluation approaches, and to sort out and harmonize various notions and measurements. How do cost effectiveness, additionality, and net welfare gain relate to each other? Is cost effectiveness the same thing as the bang for the buck? Where do econometric evaluations enter the cost/benefit analysis? This is the object of section 2 . The second objective is to assess the sensitivity of the evaluation outcome to the magnitude of certain parameters. Is additionality a must for having an effective R\&D tax incentive policy? How high must the externality parameter be to overcome the negative effect of administration costs or the 
costs of distortionary taxation? This is the object of section 3. In section 4 we report on the success of a past policy changes in the Netherlands, and we simulate the effect of various parameter changes in the existing Dutch $R \& D$ tax incentive scheme.

\section{Reconciling notions and evaluation methods}

\subsection{The notion of additionality}

The $R \& D$ tax incentive policy is aimed at making private enterprises spend more on $R \& D$ to get closer to the social optimum. The most common way to verify whether a tax incentive policy is effective is to test for additionality as opposed to crowding out of $R \& D$. If firms do nothing but substitute private $R \& D$ financing by tax support, then there is full crowding out, and the policy is clearly ineffective. If firms substitute part of their own funding by government funding, there is partial crowding out. If they spend an amount of $R \& D$ in excess of the amount of tax incentives they get from government then the policy is said to lead to additional R\&D.

Testing for additionality somehow amounts to comparing the tax expenditures with the additional amount of R\&D spent by private firms. It involves the computation of the "bang for the buck" (BFTB), which, as noted by Parsons and Phillips (2007), is also known in the literature as "incrementality ratio", "cost effectiveness ratio" or "tax sensitivity ratio". It is measured by dividing the amount of R\&D generated by the R\&D tax incentives by the net tax revenue loss (also called tax expenditures). It has not always been done correctly, as reported by Hall and van Reenen (2000). Some authors have added up all credits claimed without considering the change in the firms' tax positions because of the tax credit. For instance, in the Netherlands the tax credits that can be deducted from the firm's social security contributions are themselves taxable. Other studies have calculated the tax credits claimed taking an average firm and ignoring the firms' heterogeneity in the type of R\&D they do and in their sensitivity to the tax credits. 
The R\&D tax credits may be based on the level of R\&D and or the incremental R\&D with respect to a reference. The amount claimed by a firm may depend on the revenue position of the firm and the possibility to carry forward or backward, or to claim for refundability of, unused tax credits. The rates may vary depending on the size of the firm or its amount of R\&D. In principle, everything should be quantifiable but the researcher might not have all the information on hand to compute the claimable tax credits correctly. Moreover, there may be a difference between the tax credits computed on the basis of the reported expenditures and the statutory tax rates, the actually claimed tax credits or those finally approved by the tax authorities. And, there may a timing problem between the date the credits are claimed and the date they are received. Table 1 presents the magnitude of the cost of fiscal R\&D incentives, in absolute amount, as a proportion of GDP and in comparison with the magnitude of direct government support. It also indicates the types of R\&D fiscal incentives. Some countries, like Germany or Finland, have no R\&D tax incentives. They only have direct government support. Canada, the Netherlands and Australia rely more on R\&D tax incentives than on direct government support for R\&D. The other countries listed in table 1 rely more on direct support for R\&D.

One way to estimate the additional $R \& D$ generated by the $R \& D$ tax incentives is to ask firms directly whether tax incentives make a difference to their $R \& D$ expenditures. There is at least the suspicion that either firms do not know how much R\&D they would have done in the absence of R\&D tax credits, or that they are biased in their responses so as to be able to continue benefiting from it. It should, however, be noted that the Australian evaluation by the Bureau of Industry Economics (1993) reports consistency between declarations by firms and econometric evidence of additionality.

A more objective way to estimate the extent of additionality is to use econometric techniques. There are two broad approaches to isolate the effect of R\&D tax incentives on R\&D: the structural modeling approach and the treatment evaluation method. The structural modeling approach consists in regressing an R\&D demand equation (in terms of stocks or flows, but preferably stocks if enough observations are available to construct 
them) on its typical determinants, among which the user cost of R\&D incorporating the $R \& D$ tax parameters. A dummy taking the value one for R\&D tax credit as opposed to firms or periods without tax credits would also be feasible, but then the foregone tax revenue would be more difficult to calculate. In contrast, the user cost of $R \& D$ includes a quantification of the tax incentives via what has come to be known as the B-index. The B-index, introduced by Warda and McFetridge (1983), is defined as the ratio of the net cost of a Euro spent on R\&D, after all quantifiable tax incentives have been accounted for, to the net income from one Euro of revenue. In other words, the B-index indicates the marginal income before taxes needed for the marginal $R \& D$ investment to break even. This method has been used by Hall (1993), Bloom, Griffith and van Reenen (2002), Dagenais, Mohnen and Therrien (2004), Mairesse and Mulkay (2004), Wilson (2005), and Baghana and Mohnen (2009).

Table 1 Public support for innovation policies in various countries

\begin{tabular}{|l|l|l|l|l|}
\hline Country & $\begin{array}{l}\text { Cost of fiscal } \\
\text { R\&D } \\
\text { incentives as a } \\
\text { \% of GDP } \\
\text { incentives in } \\
\text { 2005 } \\
\text { (Millions US\$ } \\
\text { in PPP) }\end{array}$ & $\begin{array}{l}\text { Magnitude of } \\
\text { RD tax } \\
\text { government } \\
\text { funding for } \\
\text { RDD as a \% of } \\
\text { GDP }\end{array}$ & $\begin{array}{l}\text { Magnitude of } \\
\text { R\&Dect } \\
\text { support for }\end{array}$ \\
\hline Australia & $0.05(2004)$ & 356 & $0.04(2003)$ & V, I, SL, R \\
\hline Canada & $0.15(2004)$ & 2990.4 & $0.03(2004)$ & V, SL, R \\
\hline France & $0.03(2002)$ & 1009.9 & $0.15(2002)$ & V, SL, S \\
\hline Japan & $0.01(2003)$ & 3.3 & $0.02(2003)$ & I \\
\hline Netherlands & $0.09(2005)$ & 419.3 & $0.04(2003)$ & V, SL, S, R \\
\hline Norway & $0.01(2004)$ & 137.0 & $0.10(2003)$ & V, SL, R \\
\hline United Kingdom & $0.05(2004)$ & 937.3 & $0.13(2003)$ & V, SL, R \\
\hline United States & $0.06(2001)$ & 5110.0 & $0.17(2001)$ & I (mostly), R \\
\hline
\end{tabular}

Sources:

OECD Science, Technology and Industry: Scoreboard 2007;

European Commission, DG Research, "Comparing practices in R\&D tax incentives evaluation", Expert group on R\&D tax incentives evaluation.

OECD, Main Science and Technology Indicators, 2008

Cervantes (2007)

Notes:

V: volume-based; I: increment-based; SL: different treatments for small and large firms;

S: special measures for start-up firms: R: some kind of refundability 
It is important here to recognize the endogeneity of the tax credit, as the rates generally vary with the amount of $R \& D$. Likewise the dummy that tax credits have been claimed is endogenous, because firms may, for fear of being audited, sheer ignorance or compliance costs, decide not to apply for R\&D tax credits. ${ }^{1}$ Handling this endogeneity calls for good instruments. It is important to allow for the fact that the induced $R \& D$ may take time to show up because of adjustment costs in $\mathrm{R} \& \mathrm{D}$ (finding scientists and engineers, setting up a lab, devising projects). Therefore a difference should be made between short-term and long-term effects. Finally, when comparing studies one should be careful not to compare elasticities, with semi-elasticities or absolute derivatives for the price effect on R\&D.

The treatment evaluation methods consist in running quasi-experiments or constructing counterfactuals. Matching estimators compare the average R\&D effort of firms that receive $R \& D$ tax credits with the average $R \& D$ of firms that do not but that are otherwise similar, for instance in having the same likelihood of receiving R\&D tax credits but prefering not to apply for them (Czarnitzki, Hanel and Rosa, 2004; Duguet, 2007). ${ }^{2}$ The difference-in-differences estimator compare the R\&D of firms in the control and treated groups before and after a policy change, in this case a new feature in R\&D tax incentives (Cornet and Vroomen, 2005). In regression discontinuity design one compares the R\&D of firms that are affected with those that are unaffected by an exogenous discontinuity in the treatment function, for example firms just below and just above a ceiling in the conditions for being eligible to receive R\&D tax credits (Haegeland and Moen, 2007b).

Table 2 lists some of the recent studies that appeared after the well-known Hall and van Reenen (2000) survey, and summarizes the method used, the type of $R \& D$ tax credit evaluated, and the results obtained. The BFTB is typically above 1 for incremental R\&D tax credits, and below 1 for level-based R\&D tax credits.

\footnotetext{
${ }^{1}$ The latest evaluation of the R\&D tax incentives in the Netherlands (de Jong and Verhoeven, 2007) reports that for firms with less than 10 employees only one firm out of 3 applies for R\&D tax credits. ${ }^{2}$ In this particular instance, the matching estimator is perhaps not the most appropriate method because the choice of being in the treatment or in the control group is not quite exogenous.
} 
Table 2 Survey of R\&D tax credit evaluations published after Hall and van Reenen's (2000) survey paper (for a complementary survey, see Parsons and Phillips, 2007)

\begin{tabular}{|c|c|c|c|c|c|c|}
\hline Study & $\begin{array}{l}\text { Country and } \\
\text { data }\end{array}$ & Method & $\begin{array}{l}\text { Type of } \\
\text { R\&D } \\
\text { tax } \\
\text { credit }^{2}\end{array}$ & Bang for the buck & Welfare gain & Policy conclusions \\
\hline $\begin{array}{l}\text { Bloom, } \\
\text { Griffith, } \\
\text { van Reenen } \\
(2002)\end{array}$ & $\begin{array}{l}\text { Panel } \\
\text { nine OECD } \\
\text { countries } \\
1979-1997\end{array}$ & $\begin{array}{l}\text { R\&D demand } \\
\text { equation; CES prod. } \\
\text { Fct; partial adjustment }\end{array}$ & L \& I & & & $\begin{array}{l}\text { Fiscal provisions matter: } \\
\text { price elasticity of R\&D }-0.1 \\
\text { in short term, around }-1 \text { in } \\
\text { long term }\end{array}$ \\
\hline $\begin{array}{l}\text { Czarnitzki, } \\
\text { Hanel and } \\
\text { Rosa } \\
(2004)\end{array}$ & Canada & $\begin{array}{l}\text { Evaluation treatment } \\
\text { (matching estimators) }\end{array}$ & L \& I & & & $\begin{array}{l}\text { R\&D tax credit receivers } \\
\text { have higher innovative, but } \\
\text { not higher economic } \\
\text { performance }\end{array}$ \\
\hline $\begin{array}{l}\text { Dagenais, } \\
\text { Mohnen, } \\
\text { Therrien } \\
(2004)\end{array}$ & $\begin{array}{l}\text { Panel } \\
\text { Canadian } \\
\text { firm data } \\
1975-1992\end{array}$ & $\begin{array}{l}\text { R\&D demand equation } \\
\text { with endog. selection; } \\
\text { partial adjustment }\end{array}$ & L \& I & $\begin{array}{l}0.98-1.04 \text { for } \mathrm{L} \\
4.0 \text { for } \mathrm{I}\end{array}$ & & $\begin{array}{l}\text { Deadweight loss }=80 \% \text { of } \\
\text { costs to government }\end{array}$ \\
\hline $\begin{array}{l}\text { Mairesse } \\
\text { and Mulkay } \\
(2004)\end{array}$ & $\begin{array}{l}\text { France } \\
\text { Panel of firm } \\
\text { data, 1983- } \\
1997\end{array}$ & $\begin{array}{l}\text { R\&D demand } \\
\text { equation; CES prod. } \\
\text { function; } \mathrm{ECM}^{3}\end{array}$ & I & 2.0 to 3.6 & & $\begin{array}{l}\text { Incremental R\&D tax } \\
\text { incentives stimulate R\&D }\end{array}$ \\
\hline $\begin{array}{l}\text { Russo } \\
(2004)\end{array}$ & & $\begin{array}{l}\text { Computable general } \\
\text { equilibrium model }\end{array}$ & L \& I & $\begin{array}{l}\text { Higher for I than } \\
\text { for } L\end{array}$ & $\begin{array}{l}17.6 \text { elasticity } \\
\text { w/t tax } \\
\text { expend. for I, } \\
\text { unitary } \\
\text { elasticity for } \mathrm{L}\end{array}$ & $\begin{array}{l}\text { Incremental R\&D tax credits } \\
\text { dominate level-based tax } \\
\text { credits }\end{array}$ \\
\hline $\begin{array}{l}\text { Cornet and } \\
\text { Vroomen } \\
(2005)\end{array}$ & $\begin{array}{l}\text { Netherlands } \\
\text { Panel } \\
\text { Firm data } \\
\text { 1998-2003 }\end{array}$ & $\begin{array}{l}\text { Evaluation treatment } \\
\text { (difference in } \\
\text { differences) }\end{array}$ & $\mathrm{L}$ & $\begin{array}{l}\text { For starter's } \\
\text { facility: } 0.5 \text { to } 0.8 \text {, } \\
\text { for lenthening of } \\
\text { first tax-credit } \\
\text { bracket: } 0.1 \text { to } 0.2\end{array}$ & & $\begin{array}{l}\text { Without spillover effects, } \\
\text { starter's facility and } \\
\text { lengthening of first tax credit } \\
\text { bracket not effective }\end{array}$ \\
\hline $\begin{array}{l}\text { Wilson } \\
(2005)\end{array}$ & $\begin{array}{l}\text { USA } \\
\text { Panel } \\
\text { States } \\
1981-2002\end{array}$ & $\begin{array}{l}\text { R\&D demand } \\
\text { equation; CES } \\
\text { prod.function; partial } \\
\text { adjustment }\end{array}$ & L\&I & & & $\begin{array}{l}\text { Inside-state cost elasticity } \\
\text { close to - } 1 \text { in long run; out- } \\
\text { of-state elasticity almost as } \\
\text { large so that aggregate } \\
\text { elasticity close to }-0.1\end{array}$ \\
\hline $\begin{array}{l}\text { Duguet } \\
\text { (2007) }\end{array}$ & $\begin{array}{l}\text { France } \\
\text { Panel } \\
\text { Firm data } \\
1993-2003\end{array}$ & $\begin{array}{l}\text { Evaluation treatment. } \\
\text { (matching estimators) }\end{array}$ & I & $1.00-3.30$ & & $\begin{array}{l}\text { Incremental R\&D tax credits } \\
\text { stimulate } R \& D\end{array}$ \\
\hline $\begin{array}{l}\text { Haegeland } \\
\text { and Møen } \\
(2007 \mathrm{~b})\end{array}$ & $\begin{array}{l}\text { Norway } \\
\text { Panel } \\
\text { Firm data } \\
1993-2005\end{array}$ & $\begin{array}{l}\text { Evaluation treatment } \\
\text { (difference in } \\
\text { difference) }\end{array}$ & $\mathrm{L}$ & 2.00 & & $\begin{array}{l}\text { Additionality is stronger in } \\
\text { small, low-tech, and low- } \\
\text { skilled firms (i.e. firms with } \\
\text { little prior R\&D) }\end{array}$ \\
\hline $\begin{array}{l}\text { Lokshin } \\
\text { and } \\
\text { Mohnen } \\
(2007)\end{array}$ & Netherlands & $\begin{array}{l}\text { R\&D demand } \\
\text { equation; CES prod. } \\
\text { function; partial } \\
\text { adjutsment }\end{array}$ & $\mathrm{L}$ & $\begin{array}{l}0.80-1.40 \text { in short } \\
\text { run } \\
0.31-0.75 \text { in long } \\
\text { run }\end{array}$ & & $\begin{array}{l}\text { Deadweight loss due to } \\
\text { level-based tax incentives, } \\
\text { especially for large firms }\end{array}$ \\
\hline $\begin{array}{l}\text { Parsons \& } \\
\text { Phillips } \\
\text { (2007) }\end{array}$ & Canada & Cost/benefit analysis & L \& I & & $10.9 \%$ rate $^{1}$ & $\begin{array}{l}\text { R\&D spillovers are } \\
\text { necessary to justify R\&D tax } \\
\text { credits }\end{array}$ \\
\hline
\end{tabular}




\begin{tabular}{|l|l|l|l|l|l|l|}
\hline $\begin{array}{l}\text { Cappelen, } \\
\text { Raknerud, } \\
\text { Rybalka } \\
(2008)\end{array}$ & $\begin{array}{l}\text { Norway } \\
\text { panel } \\
\text { Firm data } \\
\text { Innovation } \\
\text { surveys of } \\
2001 \text { and } \\
2004\end{array}$ & $\begin{array}{l}\text { Logit for innovation } \\
\text { output with } \\
\text { endogenous R\&D tax } \\
\text { dummy. } \\
\text { Use of IV }\end{array}$ & L & & & $\begin{array}{l}\text { R\&D tax incentives increase } \\
\text { innovation in processes and } \\
\text { products new to the firm, but } \\
\text { not in products new to the } \\
\text { market and patenting }\end{array}$ \\
\hline $\begin{array}{l}\text { Baghana- } \\
\text { Mohnen } \\
(2009)\end{array}$ & $\begin{array}{l}\text { Quebec } \\
\text { Panel firm } \\
\text { data } \\
1997-2003\end{array}$ & $\begin{array}{l}\text { R\&D demand } \\
\text { equation; CES prod. } \\
\text { function; partial } \\
\text { adjustment }\end{array}$ & L \& I & & & \\
\hline
\end{tabular}

${ }^{1}$ Net welfare gain includes externalities, administration \& compliance costs, excessive burden of taxation.

${ }^{2} \mathrm{~L}=$ level based $\mathrm{R} \& \mathrm{D}$ tax credits; $\mathrm{I}=$ incremental $\mathrm{R} \& \mathrm{D}$ tax credits

${ }^{3} \mathrm{ECM}=$ error correction model

\subsection{Cost-benefit calculations or net welfare effects}

A more comprehensive computation of the effectiveness of R\&D tax incentives would require a full cost-benefit analysis. It would require computing the total (direct and indirect) costs and benefits related to the R\&D tax incentive. On the benefit side, it would mean not just computing the amount of additional R\&D but also the return on that R\&D. The return on the marginal $R \& D$ may be lower since the $R \& D$ would not have been undertaken without the tax incentive. That requires looking into the existence of secondorder and third-order effects, as explained in the following section, i.e. the effects on innovation behavior and on an economic performance measure like productivity or profitability. Another kind of secondary effect is the R\&D induced by increased output stemming from the additional R\&D (see Bernstein, 1986). There could also be a return from making firms become $R \& D$ performers ${ }^{3}$ and from attracting footloose investors (multinational companies attracted by tax incentives). A proper social cost-benefit analysis would also require incorporating R\&D spillovers, which can be positive (rent or knowledge externalities) or negative (market stealing or obsolescence).

\footnotetext{
${ }^{3}$ Hægeland and Møen (2007b) report that firms that previously did not invest in R\&D are more likely to start doing so as a result of SkatteFUNN, the Norwegian R\&D tax credit system.
} 
On the cost side of the assessment should be included implementation costs, such as hiring consultants, accountants, financial experts; administration costs such as hiring auditors, tax officers; the existence of wage effects diluting the quantity effects, intertemporal differences in the timing of costs and benefits, as well as the opportunity costs of having to raise income taxes to finance the tax incentives. A somewhat more remote possibility is that domestic R\&D tax incentives could benefit foreign firms and decrease the domestic firms' competitive position or conversely make domestic firms more receptive to international $R \& D$ spillovers. In this respect Wilson (2005) estimates that firms are very receptive to variations in the within-state $R \& D$ tax incentives, but also almost to the same extent to variations in the best out-of-state $R \& D$ tax incentives, with a net aggregate effect close to 0 .

\subsection{Second-order and third-order effects}

It is not sufficient to show additionality in $R \& D$, the additional $R \& D$ should also yield a positive rate of return for there to be a private benefit. A number of studies have examined the effects of tax incentives on various measures or aspects of innovation (patents, the share of innovative products in total sales, the propensity to come up with new products, new to the firm or new to the market). These phenomena are referred to as behavioral innovations, i.e. the way firms behave differently in terms of innovation output. They are also often referred to as second-order effects as opposed to first-order effects (on R\&D) and third-order effects (on firm performance measures such as productivity or profitability).

Second- and third-order effects can be estimated within some version of the CréponDuguet-Mairesse (CDM) model. It consists in modeling R\&D intensity, innovation output (INNO) and productivity (PROD) as a system of simultaneous equations. In a first equation, firm's R\&D is explained by the R\&D tax credits (TC) and other controls; in the second equation firm's share of innovative products in total sales is explained by the 
R\&D intensity; and in a third equation total factor productivity (level or growth) is explained by the share of innovative sales:

$$
\left\{\begin{array}{l}
R \& D_{i t}=\mathbf{Z}_{i t} \beta+X_{i t} \delta+\alpha T C_{i t}+\theta_{i}+u_{i t} \\
I N N O_{i t}=\Pi_{i t} \varphi+\psi R \& D_{i t}+\gamma_{2} \theta_{i}+\varepsilon_{i t} \\
P R O D_{i t}=\mathbf{W}_{i t} \eta+\kappa \hat{N} N O_{i t}+\gamma_{3} \theta_{i}+v_{i t}
\end{array}\right.
$$

where each equation has a random error component and $\theta_{i}$ is an individual effect that plays out differently in each equation (in the case of panel data). The system of simultaneous equations (1) can be estimated by asymptotic least squares or instrumental variable methods and allows estimating the second- and third-order effects of the fiscal incentives. If estimated in logs, the coefficient $\psi$ can be interpreted as the elasticity of the innovative output with respect to $R \& D$, which in turn is a function of the fiscal incentives and other covariates. The second-order effect of the tax credits can be computed as the product of the partial effects (elasticities if variables are in logs):

$$
\frac{\partial I N N O}{\partial T C}=\frac{\partial R \& D}{\partial T C} \cdot \frac{\partial I N N O}{\partial R \& D}=\alpha \cdot \psi
$$

Similarly, a third-order effect of the fiscal incentives on firm productivity can be computed as the product of the three partial effects (elasticities):

$$
\frac{\partial P R O D}{\partial T C}=\frac{\partial R \& D}{\partial T C} \cdot \frac{\partial I N N O}{\partial R \& D} \cdot \frac{\partial P R O D}{\partial I N N O}=\alpha \cdot \psi \cdot \kappa .
$$

Lokshin and Mohnen (2007a) report for the Netherlands a short-run elasticity of R\&D to the user cost of R\&D 0.77, an elasticity of the share of innovative sales to the R\&D intensity of 0.52 and an elasticity of total factor productivity growth to the share of innovative sales of 0.07 . The total elasticity of PROD with respect to TC is thus equal to 0.028 , implying that a $10 \%$ increase in tax credits would increase (labor) productivity by $0.28 \%$. The advantage of the simultaneous-equations model over reduced form models is 
that it permits to disentangle the effects of tax incentives on innovation input, innovation output and productivity.

Another approach would be to estimate directly a reduced form of innovation or economic performance on the user cost of R\&D. This approach is attractive for its simplicity. It was used by Brouwer et al. (2002) in the first official evaluation of the R\&D tax incentive for the Netherlands. They regressed various innovation output measures such as the share in total sales of innovative products on received tax credits and found that a $1 \%$ higher amount of tax credits leads to a $19 \%$ higher share of innovative sales in the short-run. Similarly, Cappelen et al (2008) use this approach on two cross-sections of Norwegian firms for 2001 and 2004 to study the effects of the Norwegian SkatteFUNN R\&D support scheme on firm innovation activities and patenting. They find that the SkatteFUNN credits have a positive impact on the new (or improved) product for the firm, but not the new (or improved) product for the market.

Parsons and Phillips (2007) calculate the net welfare gain of R\&D tax incentives following the cost-benefit framework suggested by Lattimore (1997). From a comprehensive survey of estimates reported in the literature, they take the median values of the R\&D incrementality ratio (0.86) and of the domestic external rate of return to $R \& D$ (0.56), and they compute an average marginal excess burden of taxation of 0.27 . The compliance and administration costs in proportion of the tax incentives provided are set at $8 \%$ and $2 \%$ respectively. ${ }^{4}$ For these parameter values, they estimate a net welfare effect per dollar of tax expenditure of $10.9 \%$.

\section{Sensitivity analysis}

It is a daunting task to assess the exact magnitude of all the elements that enter a proper cost-benefit analysis. It involves parameter estimates with more or less high standard errors. An alternative would be to perform a sensitivity analysis by simulating the

\footnotetext{
${ }^{4}$ The recent Dutch evaluation of its R\&D tax incentive system (de Jong and Verhoeven, 2007) reports compliance and administration costs of $7 \%$ and $2 \%$, figures that are very close to those reported for Canada (Parsons and Phillips, 2007).
} 
benefit-cost ratio using ranges of reasonable estimates of $\mathrm{R} \& \mathrm{D}$ responsiveness, opportunity costs, externalities, administration and implementation costs, rates of time preference, differential responsiveness by firm size, or possible differences in the rates of return on marginal $R \& D$ projects stimulated by the tax incentives compared to the rates of returns earned on already performed $R \& D$ projects, to see what patterns of estimates of the various determinants would produce a positive net welfare gain. An exercise of this kind is conducted by Parsons and Phillips (2007) for Canada. They report for instance that the domestic external return would have to fall to 0.45 or the incrementality ratio to 0.71, all other things equal, to produce a net welfare loss per dollar of R\&D tax incentive. Nevertheless they conclude that for a reasonable range of estimates the net welfare gain of $R \& D$ tax incentives is positive.

Instead of comparing the costs and benefits in the period just after the introduction of a new policy or at the new long-run equilibrium (assuming it gets reached in one shot), we argue that it is more appropriate to compare the whole sequence of costs and benefits, in discounted present value terms, before and after the introduction, the removal or the modification of $R \& D$ tax incentives. The timing at which costs and benefits occur may make a difference. Costs and benefits may be spread out over time because of adjustment costs in $\mathrm{R} \& \mathrm{D}$, delays in getting the $\mathrm{R} \& \mathrm{D}$ tax credits, or inter-temporal connections between tax credits as in the case of incremental R\&D tax credits. This type of reasoning has been applied in Dagenais, Mohnen, Therrien (2004) and Lokshin and Mohnen (2007b).

In our sensitivity analysis of the incrementality ratio (or bang for the buck) to the elements that enter a proper cost-benefit analysis, we draw on the approach proposed in Lokshin and Mohnen (2007b). The latter contribution estimates a dynamic factor demand model. Assuming a CES approximation to the production function, static expectations on prices and output, it obtains an expression for the long-run optimal R\&D stock, which is a function of firm and industry output and the price of $R \& D$ (user cost). Dynamics is introduced into the model by assuming that the R\&D stock follows a partial adjustment mechanism. The expression for the user cost, which plays a central role in firms' 
decisions to increase/decrease $R \& D$ investments, is derived from the equality between the discounted value of the net (after income tax) "rental" cost of a unit of R\&D and the net (of tax incentives) purchase price of that same unit and is given by the following expression:

$u_{R i}=P_{R}(r+\delta) \frac{1}{1-\tau}\left\{1-(1-\tau) w_{i}^{L} \gamma_{i}\left(R_{i}\right)-\tau \kappa_{i}\right\}$

where $P_{R}$ is the R\&D deflator, $\mathrm{r}$ is the real interest rate, $\delta$ is the depreciation rate of the stock of knowledge assumed to be $15 \%, \tau$ is the corporate income tax rate, $w_{i}^{L}$ is the percentage of labor costs in total R\&D, $\gamma_{i}\left(R_{i}\right)$ is the fraction of private $\mathrm{R} \& \mathrm{D}$ supported by the tax incentive program, itself taxable, and $\kappa_{i}$ is the fraction of total $R \& D$ expenditures that can be immediately expensed. ${ }^{5} \gamma_{i}($.$) depends on R_{i}$ because firms that fall in the second bracket of R\&D expenditures benefit from a lower rate of R\&D tax credit. $\kappa_{i}$ is different from one because the capital expenditures part of R\&D cannot be immediately expensed.

Using the estimated short- and long-run elasticities from such factor-demand model we propose to measure the bang for the buck by the following expression:

$B F T B=\frac{\sum_{i} \sum_{t=1}^{\infty}\left(\widetilde{R}_{i t}-R_{i t}\right) /(1+r)^{t-1}}{\sum_{i} \sum_{t=1}^{\infty}\left(\widetilde{W}_{i t}-W_{i t}\right) /(1+r)^{t-1}}$.

where $R_{i t}$ is the R\&D expenditure of firm $\mathrm{i}$ in period $\mathrm{t}$ that the firm would have incurred in the absence of a change in the R\&D tax credit and $\widetilde{R}_{i t}$ the corresponding R\&D

\footnotetext{
${ }^{5}$ For more details on the construction of the user cost of R\&D for the Netherlands, see Lokshin and Mohnen (2007b).
} 
expenditure after the change in the R\&D tax credit; $W_{i t}$ and $\widetilde{W}_{i t}$ are the respective $R \& D$ cost of firm i supported by government.

To illustrate our proposed measure of cost effectiveness and its sensitivity to the incorporation of costs and benefits other than those directly related to changes in the $R \& D$ tax incentives, we simulate a set of 1000 observations, replicating the composition of the Dutch population of $R \& D$ performers. The Dutch $R \& D$ tax incentive scheme, known as WBSO, allows firms to deduct from their social security contributions $40 \%$ of their R\&D labor costs up to $€ 110,000$ and $14 \%$ of the remainder with a cap on total tax incentives of $€ 7.9$ million. We assume that the R\&D stock adjusts to its desired level by a partial adjustment mechanism, whereby in every period a fraction $\lambda$ of the desired adjusment is accomplished. We use the estimated R\&D price elasticities and adjustment speeds of R\&D (parameters $\sigma \lambda$ and $\lambda$ ) estimated in Lokshin and Mohnen (2007b) for Dutch firms: an estimated $\lambda$ of 0.58 for large firms and 0.51 for small firms, an estimated short-run price elasticity of R\&D stock $\sigma \lambda$ of 0.11 for large firms and 0.31 for small firms, and a long-run price elasticity $\sigma$ of 0.20 for large firms and 0.61 for small firms. ${ }^{6}$

Our simulated data set is constructed as follows: in the first step we draw a random sample of 1000 observations on R\&D from a uniform distribution with a minimum of $€ 500$ and a maximum corresponding to the first bracket ceiling of $€ 110,000$. This subsample represents a cohort of small firms and starters whose R\&D expenditures fall entirely in the first bracket. In the second step, we similarly draw another sample of 1000 observations on R\&D from a uniform distribution with a minimum of 110,001 Euro and a maximum that corresponds to a total of tax support set at $€ 7.9$ million. This sub-sample represents a cohort of larger firms whose R\&D expenditures span over the two brackets. Our final sample on which we perform simulation experiments corresponds to $75 \%$ of observations randomly drawn from the first cohort and $25 \%$ observations randomly

\footnotetext{
${ }^{6} \mathrm{~A}$ higher R\&D price elasticity for small firms vis-à-vis large firms is also reported in Baghana and Mohnen, 2009.
} 
drawn from the second cohort. ${ }^{7}$ The mean R\&D of the small- and big-firm cohorts are $€ 56,000$ and $€ 3,907,000$, respectively, with an overall sample mean of $€ 956,000$.

In addition to the random sample, and in order to increase the variation in the subsequently constructed user cost, we randomly draw a number of other parameters. We draw the share of labor $R \& D$ expenditures from a normal distribution with a mean of 0.7 and a standard deviation of 0.18 . We truncate the maximum of the wage share to unity. We then create the remaining $R \& D$ expenditure shares mimicking the actual data values (share of R\&D spent on equipment, buildings and other R\&D expenditures), ensuring that all the shares sum up to unity.

In the final step, we construct the user cost of R\&D using the simulated $R \& D$ data using expression (5).

Using the simulated $R \& D$ data that mimics the population of $R \& D$ performers in the Netherlands, and the estimated parameters from the dynamic factor-demand model, we are in a position to carry-out a number of experiments to examine how the incrementality ratio would change in response to changes in the tax incentives scheme, firm's tax positions, externalities, administration and implementation costs. We conduct the following experiments: 1) complete removal of the tax incentives scheme (our, benchmark case) 2) sensitivity to changes in rates of time preference, differential responsiveness by firm size 3) sensitivity to the inclusion of administration costs, social rates of return, i.e. spillovers. We begin with the base case, computed according to equation (5), which we summarize in Table 3 below.

\footnotetext{
${ }^{7}$ In the Netherlands SMEs make up about $75 \%$ of all firms (see de Jong and Verhoeven, 2007).
} 
Table 3 Components for the computation of the bang for the buck (equation (4))

\begin{tabular}{|c|c|c|}
\hline time & Change in R\&D expenditures $\left(\widetilde{R}_{t}-R_{t}\right)$ & Change in foregone tax revenues $\left(\widetilde{W}_{t}-W_{t}\right)$ \\
\hline 1 & $\left(\partial K_{1} / \partial u_{R}^{1}\right) \Delta u_{R}^{1}$ & $(1-\tau) w^{L}\left[\widetilde{\gamma}\left(\widetilde{R}_{1}\right) \widetilde{R}_{1}-\gamma\left(R_{1}\right) R_{1}\right]+\tau \kappa\left(\widetilde{R}_{1}-R_{1}\right)$ \\
\hline 2 & $\delta\left(\partial K_{1} / \partial u_{R}^{1}\right) \Delta u_{R}^{1}+\left(\partial K_{2} / \partial u_{R}^{1}\right) \Delta u_{R}^{1}$ & $(1-\tau) w^{L}\left[\widetilde{\gamma}\left(\widetilde{R}_{2}\right) \widetilde{R}_{2}-\gamma\left(R_{2}\right) R_{2}\right]+\tau \kappa\left(\widetilde{R}_{2}-R_{2}\right)$ \\
\hline 3 & $\delta\left(\partial K_{1} / \partial u_{R}^{1}+\partial K_{2} / \partial u_{R}^{1}\right) \Delta u_{R}^{1}$ & $(1-\tau) w^{L}\left[\widetilde{\gamma}\left(\widetilde{R}_{3}\right) \widetilde{R}_{3}-\gamma\left(R_{3}\right) R_{3}\right]+\tau \kappa\left(\widetilde{R}_{3}-R_{3}\right)$ \\
\hline$\cdot$ & $+\left(\partial K_{3} / \partial u_{R}^{1}\right) \Delta u_{R}^{1}$ & \\
\hline $\mathrm{t}$ & $\delta\left(\partial K_{1} / \partial u_{R}^{1}+\partial K_{2} / \partial u_{R}^{1}+\ldots+\partial K_{t-1} / \partial u_{R}^{1}\right) \Delta u_{R}^{1}$ & $(1-\tau) w^{L}\left[\widetilde{\gamma}\left(\widetilde{R}_{t}\right) \widetilde{R}_{t}-\gamma\left(R_{t}\right) R_{t}\right]+\tau \kappa\left(\widetilde{R}_{t}-R_{t}\right)$ \\
& $+\left(\partial K_{t} / \partial u_{R}^{1}\right) \Delta u_{R}^{1}$ & \\
\hline
\end{tabular}

Notes: $\mathrm{R}$ stands for $\mathrm{R} \& \mathrm{D}$ expenditures, $\mathrm{K}$ for $\mathrm{R} \& \mathrm{D}$ stock, $\delta$ is the depreciation rate of the $\mathrm{R} \& \mathrm{D}$ stock, the subscripts correspond to time periods starting with period 1 when the policy shock takes place, superscript $\sim$ denotes values after the policy shock. The derivative $\partial K_{j} / \partial u_{R}^{1}$ represents the change in desired $R \& D$ stock in period $j$ after the change in the user cost of $R \& D$ due to a change in R\&D tax incentives in period $1\left(\Delta u_{R}^{1}\right)$. In Lokshin and Mohnen's (2007b) model, it is given by $\frac{\partial K_{i}}{\partial u_{1}^{R}}=-\sigma \lambda(1-\lambda)^{t-1} \frac{\widetilde{K}_{t}}{u_{1}^{R}}$.

In our base experiment we assess the costs and benefits of a complete removal of $R \& D$ tax credits, i.e. setting $\tilde{\gamma}()=$.0 . This policy shock leads to an increase in the user cost of R\&D. As a consequence, firms decrease their $R \& D$ investment and at the same time government no longer needs to support the WBSO. When the adjustment to the new optimal R\&D stock is completed firms have reached a new steady state with lower R\&D expenditures and as a result a decreased optimal R\&D stock. Firms, from whatever position they are in (it need not be a steady state equilibrium), strive to adjust to the new steady state corresponding to the change in the user cost of R\&D. To arrive at the new 
steady-state R\&D stock firms decrease their R\&D investment and hence government saves on foregone tax revenues by no longer supporting the R\&D incentive scheme.

In order to track how the incrementality ratio (4) changes over time as firms adjust to the new steady state we need to compute changes in R\&D flows (and associated government expenditures for $R \& D$ support) for each firm from time $t=1$ onwards. Table 3 summarizes the old and the new trajectory of R\&D flows for a particular firm (for ease of notation the index $\mathrm{i}$ has been removed) and the tax revenues foregone by government from period one onwards. As we assume a geometric adjustment towards the new steady state, it will theoretically take for forever to reach the new desired stock, although it is essentially reached after 15 to 20 years. In order to estimate the BFTB we compute the ratio of the accumulated discounted differences in $R \& D$ expenditures from period one onwards till infinity between the two scenarios (with and without the R\&D tax credits) to the accumulated discounted government savings due to the scheme's removal.

Since the tax support is more generous towards small and medium sized enterprises, it is of interest to compare the effectiveness of the tax credit policy for SMEs and large enterprises. To illustrate the impact of the removal of the R\&D tax scheme, Figure 1 plots the estimated BFTB, which is computed as given in equation (5) and according to the evolution given in Table 3. We report the plots for small firms (whose R\&D falls entirely in the first bracket of the Dutch R\&D tax incentive scheme) and for bigger firms (whose R\&D spans over the two brackets of the scheme). The BFTB after one period is above unity only for smaller firms. But, it declines rapidly and converges to a point slightly below unity for small firms and well below unity for large firms. Although our sample is created so as to mimic the actual population of scheme's users, the overall BFTB line is closer to the one that pertains to large firms, the total $R \& D$ of which dominates the sample. 
Figure 1: Mean BFTB after t years: all, large, and small firms

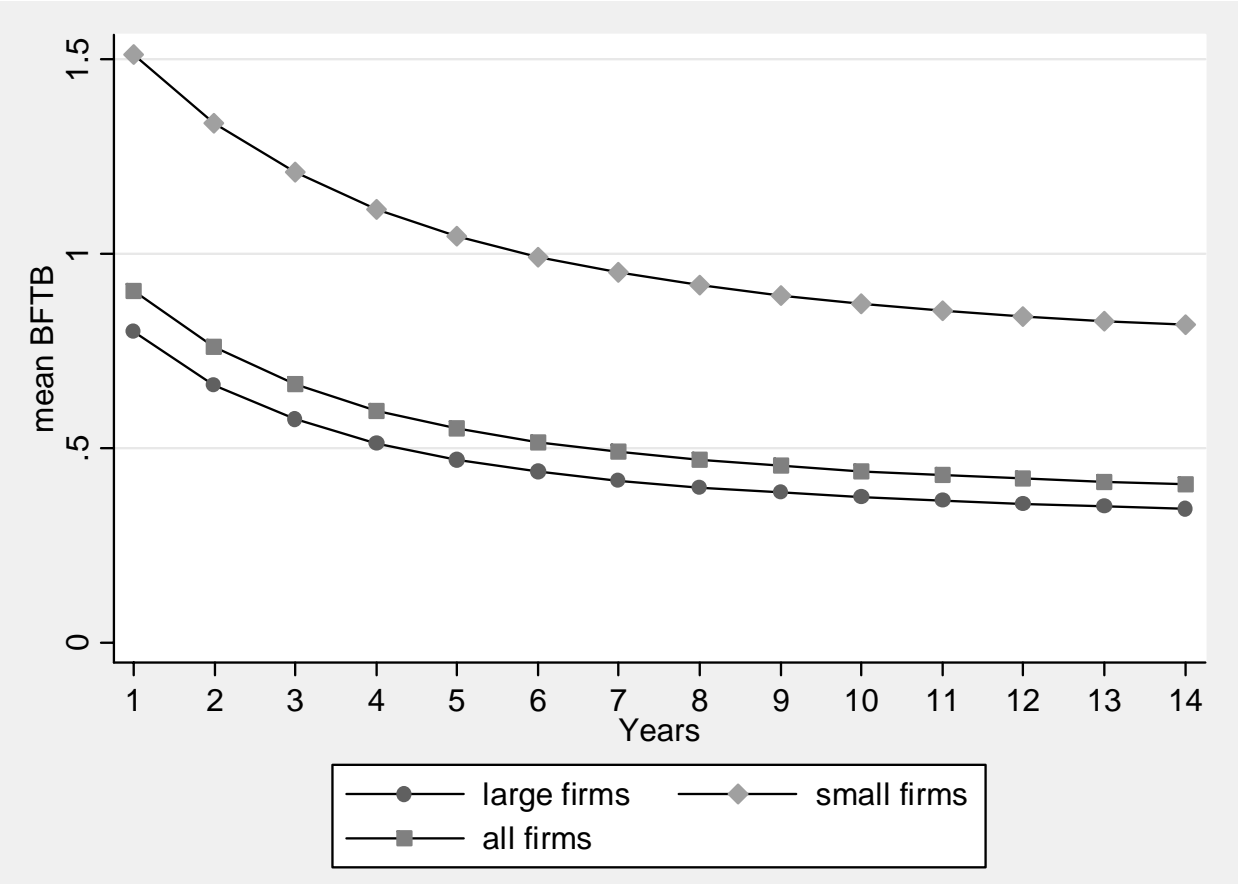

The rapid decline of the BFTB is due to the transfer cost (or deadweight loss) caused by the level-based nature of the fiscal incentive scheme. Intuitively, government supports any increment in R\&D to the extent that it allows this R\&D to be immediately expensed (in some countries, but not in the Netherlands, it also provides an increment-based R\&D tax credit), but by introducing the level-based WBSO the Dutch government also supports the level of R\&D that existed at the time the policy was introduced, i.e. an amount of R\&D that would have been performed in the absence of the tax credits. The support of the latter is a deadweight loss from the social planner's perspective. The transfer cost amounts to $88 \%$ of the total cost accruing to the government for supporting the tax incentive scheme. The latter is computed by adding the first terms in the second column of table 3 and dividing it by the sum of the total elements of column 2 (summing over all firms and appropriately discounting).

Given our modeling assumptions, the curvature of the evolution of the BFTB curve and the behavior of R\&D investment can be shown to depend on the R\&D stock depreciation rate $\delta$, the partial adjustment coefficient $\lambda$ and the discount rate $(1+\mathrm{r})^{-1}$. The increase in 
adjustment coefficient leads to a steeper BFTB curve and an upward shift of the curve. The increase in depreciation rate $\delta$ leads to flatter curve and downward shift in the curve. Figure 2 illustrates the difference in the cumulative bang for the buck for three scenarios: the baseline case, reproducing the middle curve in Fig.1, and the curves that correspond to a higher speed in the adjustment of R\&D stock (0.65 instead of 0.5) and a higher depreciation rate for the $\mathrm{R} \& \mathrm{D}$ stock ( 0.25 instead of 0.15$)$.

Figure 2: Mean BFTB after t years, all firms

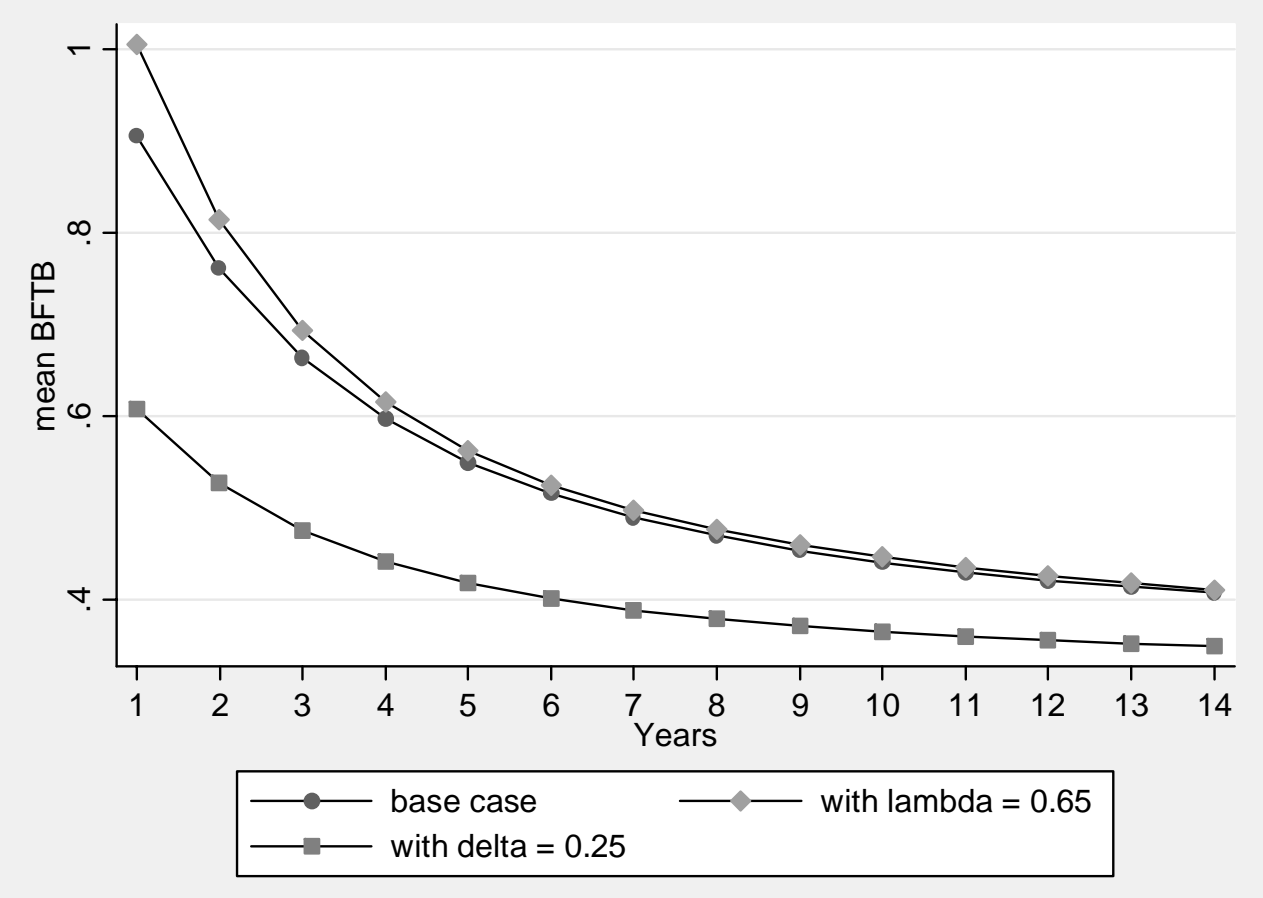

In all our experiments so far we observe that firms respond to the removal of $R \& D$ tax credits by decreasing their $R \& D$ investment in the first period following the policy change; however their R\&D behavior in the subsequent periods depends on the relative magnitudes of $\delta$ and $\lambda$. It can be shown (the proof is available from authors upon request) that in the model of Lokshin and Mohnen (2007b) an initial drop in R\&D expenditures due to the removal of the level-based $R \& D$ tax credit will be followed by a lower drop (compared to the initial level of $R \& D$ expenditures) in the subsequent periods 
when $\delta<\lambda$. When $\delta>\lambda, \mathrm{R} \& \mathrm{D}$ levels will keep declining more and more until a new steady state is reached. We observe that small firms are quite responsive to the shock. The initial drop (from $t=1$ to $t=2$ ) in average $R \& D$ spending is steeper for smaller firms compared to large firms: it is about $55 \%$ for small firms and $7.5 \%$ for large firms. The total drop from the initial shock to the point of convergence some 10 periods later is about $16 \%$ for the small firms and is only $2.0 \%$ for the large firms.

To do a more accurate cost-benefit analysis we shall follow the example of Parsons and Phillips (2007) and compute a net welfare gain including the BTFB, the social return to R\&D, administration and compliance costs, and the cost of distortionary taxes. Accounting for the social rate of return to R\&D, i.e. including the effects of $R \& D$ spillovers, amounts to multiplying the numerator of equation (5) by $(1+\varphi)$ where $\varphi$ is the social rate of return to $R \& D$ and subtracting the taxes paid on the social returns to $R \& D$ from the tax revenues foregone in the denominator. Accounting for administration and compliance costs (c) amounts to multiplying that part of the denominator of (4) that relates to the $R \& D$ tax credit (the first terms in column 2 of table 3 ) by $(1+c)$. Accounting for the costs of distortionary taxes (d) amounts to multiplying the whole denominator of (5) by $(1+d)$.

Several parameters, such as the interest rate and the corporate income tax rate, that we use in the simulation reproduce the Dutch data. The remaining parameters are allowed to take a range of values and allow us to examine the robustness of the outcomes to variations in these parameters. For example, to examine the sensitivity to the social returns to $\mathrm{R} \& \mathrm{D}$ (which include $\mathrm{R} \& \mathrm{D}$ spillovers) we take a range from $10 \%$ to $50 \%$. Values of $50 \%$ do not seem to be extraordinary large. For example, most of the calibration outcomes reported in Jones and Williams (2000) produce values of R\&D spillovers greater than $40 \%$. The administration and compliance costs roughly correspond to the values reported from face-to-face interviews with firm managers and government agency administrators in the latest evaluation of the Dutch WBSO program (de Jong and Verhoeven, 2007) 
In table 4 we summarize the outcomes of various sensitivity analyses on the short-run and long-run net welfare gains. Introducing a 10 percent administration and compliance cost decreases even further the benefit/cost ratio, although its effect on the long-run welfare gain appears minimal. Adding a 30 percent additional cost of distortionary taxation reduces the benefit/cost ratio even further down to 0.28 in the long run. When we express the benefits in terms of social returns assuming a $10 \%$ social rate of return on $R \& D$, we obtain a net welfare gain of 7 percent in the short run and of 3 percent in the long run. If we allow for a $30 \%$ social rate of return the net welfare gain rises to 22 percent in the short run and 9 percent in the long run. If we put the social rate of return to $50 \%$ (which is close to the median return reported by Parsons and Phillips (2007) the net welfare gain rises to 38 percent in the short run and 16 percent in the long run. The long-run outcomes are always smaller than the short-run outcomes because of the deadweight loss. The 16 percent net welfare gain from $R \& D$ tax incentives in the Netherlands is close to the 11 percent figure reported by Parsons and Phillips (2007).

Table 4 Benefit/cost analysis from a removal of level-based R\&D tax credits

\begin{tabular}{|c|c|c|c|}
\hline & Scenarios & $\begin{array}{l}\text { Short-run net } \\
\text { welfare gain }\end{array}$ & $\begin{array}{l}\text { Long-run net } \\
\text { welfare gain }\end{array}$ \\
\hline & Base case & & \\
\hline \multirow[t]{2}{*}{1} & Bang for the buck & 0.91 & 0.37 \\
\hline & Adding to the base case & & \\
\hline 2 & 10 cent administration and compliance cost & 0.84 & 0.34 \\
\hline 3 & $\begin{array}{l}10 \text { cent administration and compliance cost, and } \\
30 \% \text { cost of distortionary taxation }\end{array}$ & 0.65 & 0.26 \\
\hline 4 & $\begin{array}{l}10 \text { cent administration and compliance cost, } 30 \% \\
\text { cost of distortionary taxation and } 10 \% \text { social rate of } \\
\text { return }\end{array}$ & 0.07 & 0.03 \\
\hline 5 & $\begin{array}{l}10 \text { cent administration and compliance cost, } 30 \% \\
\text { cost of distortionary taxation and 30\% social rate of } \\
\text { return }\end{array}$ & 0.21 & 0.09 \\
\hline \multirow[t]{2}{*}{6} & $\begin{array}{l}10 \text { cent administration and compliance cost, } 30 \% \\
\text { cost of distortionary taxation and } 50 \% \text { social rate of } \\
\text { return }\end{array}$ & 0.36 & 0.15 \\
\hline & BFTB for different size distributions & & \\
\hline 7 & $43 \%$ of small firms & 0.94 & 0.40 \\
\hline 8 & $23 \%$ of small firms & 0.83 & 0.34 \\
\hline
\end{tabular}




\section{Policy experiments}

Parameters of the fiscal incentive schemes rarely stay constant over time. Governments may wish to give an additional boost to $R \& D$ or increase the stimulus for a particular target group (e.g., starting firms, small and medium sized enterprises, etc.). For example, the Dutch scheme parameters have varied a number of times since 1994. The first bracket ceiling was extended from $€ 45,000$ to $€ 68,000$ (in 1996), later to $€ 90,000$ (in 2001) and most recently to $€ 110,000$ (in 2004). The first bracket rate was increased from $25 \%$ to $40 \%$ in 1996 and most recently to $42 \%$ (in 2004). The second bracket rate was increased most recently from $13 \%$ to $14 \%$ (in 2004). A special first bracket rate exceeding the normal first bracket rate by $20 \%$ was introduced for starting firms in 2001. A question that naturally arises is how sensitive firms are to marginal changes in the fiscal incentive scheme parameters. In order to answer this question, we performed some additional experiments in which we simulated the effect of a marginal change in a parameter of the tax scheme holding all other parameters constant.

Changes in the scheme's parameters lead to changes in the user cost and may thus affect a firm's R\&D decisions. From our experiments we conclude, however, that the impact on the user cost is not substantial when the changes in the tax scheme's parameters are small. For example, an increase in the first bracket rate of $2 \%$ results in a change of the B-index from 0.71 to 0.73 in our simulated sample and a decrease of the user cost of $0.2 \%$ on average for firms which are in the first bracket and has practically no impact on the larger firms. The decrease in the user cost prompts a modest response in terms of the increased R\&D spending of about $2.5 \%$ in the first period (for small firms), which gradually declines to about $1.3 \%$ in the long run. The results also suggest that the response for large firms to changes in the first bracket rate in terms of additional R\&D is negligible.

When the first bracket length is extended by $€ 20,000$ or the second bracket rate is increased by $1 \%$ we observe very little change in the user cost (magnitudes of the order of $0.1 \%$ ). The increase in R\&D levels due to the extension of the first bracket, even for 
small firms, is about $0.3 \%$ in the short run. The increase in R\&D levels for large firms due to the increase in the second bracket rate is about $0.5 \%$ in the short run. This latter experiment is of course not relevant for small firms, whose R\&D by definition lies entirely in the first bracket.

Our experiments with introducing marginal changes in the schemes's parameters show that in terms of the increased $R \& D$ spending the impact of marginal changes in the fiscal incentive scheme are limited. The most promising change from the policy perspective is the increase in the first bracket rate which prompts almost a proportional increase in the R\&D spending in small firms, but this effect declines as firms adjust to the new steady state. We find minimal impact of the marginal changes in the scheme's parameters in terms of the R\&D spending for large firms.

It is often the case that fiscal incentive schemes aim a particular target group. This could be small and medium size enterprises, young firms or firms in a particular (technological) sector. The policy of preferential treatment of small firms is justified from the point of view of government because SMEs are likely to be more reactive to the changes in R\&D tax incentives. On the one hand, this is due to their relatively greater difficulty in financing their $R \& D$ as a result of having little collateral; on the other hand, they may be young firms with little to show in terms of success, they may not even have patents to signal their capability to innovate.

The simulation experiments that we carried out so far suggest that the preferential treatment of smaller firms for $R \& D$ tax credits is justified. $R \& D$ tax credits are more effective in stimulating R\&D investment in small firms and are quite wasteful in terms of cost-benefit for large firms. As a final experiment we investigate the impact in terms of the cost-benefit of a compositional change in the population of users. We do this by drawing a sample of 1000 observations from a uniform distribution with a minimum of $R \& D$ expenditures of $€ 500$ and a maximum set equal to $€ 250,000$ in one case, which corresponds to an R\&D department of about 5 people and to $€ 500,000$ in the second case. 
When the maximum R\&D is set at $€ 250,000$ the share of small firms in our sample is $43 \%$ and the share of their $R \& D$ in the total is $20 \%$. The results of these experiments are summarized in Table 4. The initial BFTB for the whole sample is close to unity, and it is well below unity in the long run. Increasing the maximum R\&D to $€ 500,000$ reduces the share of small firms to $23 \%$ and the share of their R\&D to $5 \%$, while the BFTB for the whole sample becomes even smaller. Increasing the share of small firms (which, as before, are defined as those with an R\&D that falls entirely in the first bracket) increases the overall BFTB, but not by a substantial amount.

The Cornet and Vroomen (2005) study is one of the few that have evaluated the effectiveness of changes in the R\&D incentive scheme. They examined the result of two changes in the Dutch WBSO system that were introduced in 2001: the increase of the ceiling of the first bracket from $€ 68,067$ to $€ 90,756$ and the introduction of the starter's facility that provides an extra 20 percent tax credit for firms in the first bracket. Using counterfactuals analyses, the authors find that the increase of the first bracket ceiling yields a BFTB of only 10 to 20 cent and the introduction of the starter's facility a BFTB of 50 to 80 cent. The low estimates could in part be due to difficulties in identifying the respective effects, but are also in line with the results of our simulation.

\section{Conclusion}

In this paper we have tried to demystify the conventional wisdom that an effective tax incentive policy should lead to a cost effectiveness ratio, or bang for the buck, greater than one. With level-based tax incentives, this ratio can quickly fall below one because of a transfer cost, or deadweight loss, resulting from supporting R\&D that would be done anyway. In this sense, level-based tax incentives are akin to R\&D subsidies. A costeffectiveness ratio smaller than one is, however, not sufficient to condemn the R\&D tax incentive policy for being inefficient. What matters is the net welfare gain of such a policy, i.e. whether the social return of the additional R\&D exceeds the net compliance, administration, and opportunity costs of public funding. 
We performed a sensitivity analysis by simulating the net welfare gain under various scenarios and parameters. Our general conclusion is that using reasonable estimates of the various components of the net welfare gains and simulated data representative of the Dutch population of $R \& D$ performers, the $R \& D$ tax incentive scheme leads to a positive net welfare gain. We further conclude that in the presence of adjustment costs in $R \& D$, administrative delays in paying the tax incentives, or other reasons for irregular and asymmetric distributions of costs and benefits over time, it is important to consider the time path of the realizations of the social costs and benefits, as we have illustrated in section 3 .

In addition to the sensitivity analysis we also performed a number of policy experiments to examine the relative effectiveness of the incremental changes in fiscal incentives scheme's parameters on stimulating additional private R\&D. In particular, we considered the following effects 1) changes in fiscal incentives scheme parameters 2) compositional changes in fiscal incentives scheme's beneficiaries. The logic behind these experiments is that changes in the tax scheme parameters lead to changes in the user cost of R\&D and may therefore affect a firm's R\&D decisions. Based on our experiments, we conclude, however, that the response, especially for the large firms, to changes in the first bracket rate in terms of additional $R \& D$ is negligible. Our general conclusion is that changing the value of the $R \& D$ tax parameters does not make a great difference in terms of net welfare gains.

In designing a fiscal incentive scheme an important choice to be made by policymakers is between a level-based and an increment-based R\&D tax credit system. With a levelbased system (volume regulation) any R\&D performed is eligible for tax credits, whereas with an increment-based system only $R \& D$ that exceeds a base level is eligible for $R \& D$ tax credits. The reference point in the incremental scheme can be the amount of R\&D in a reference year or the average expenditures over a number of years. Most countries that have a fiscal incentive scheme opt for a volume-based regulation. 
Few countries implement the incremental system, e.g. the United States, Spain, Ireland, Portugal and, up to recently, France (Nill, 2005). There are good reasons for it. First, increment-based schemes are more difficult and costly to administer. Second, they lead to market distortions and uncertainty among firms. Indeed they encourage firms to have a cycling R\&D behavior to maximize the benefits of tax incentives (see Hollander, Haurie and L'Ecuyer, 1987 and Lemaire, 1996). Third, they are limited in their effects as any increase in $R \& D$ in a given year reduces the possibility to claim tax credits in future years (at least when the reference base is a moving base).

However, as we have shown, volume-based schemes are inefficient because they involve large transfer costs by supporting pre-existing $R \& D$ that would have been done even in the absence of R\&D tax credits, a weakness not shared by incremental R\&D tax credit schemes. While previous research acknowledges the transfer cost in the volume-based schemes (e.g. Russo, 2004), which tends to lead to a bang for the buck below one, the value of one is still largely considered as the sign of an effective tax incentive policy. But even if the cost effectiveness ratio is below one, a level-based $R \& D$ tax incentive policy could still be defended of spillovers are large enough (as also argued by Russo (2004), Cornet and Vroomen (2005), Wilson (2005), and Parsons and Phillips (2007)).

\section{References}

Baghana, R. and P. Mohnen (2009), "Effectiveness of R\&D tax incentives in small and large enterprises: analysis of firm data in Québec", Small Business Economics, forthcoming.

Bernstein, Jeffrey I. (1986), "The Effect of Direct and Indirect Tax Incentives on Canadian Industrial R\&D Expenditures", Canadian Public Policy, 12(3), 438-448.

Bloom, N., Griffith, R. and Van Reenen, J. (2002), "Do R\&D Credits Work? Evidence From A Panel Of Countries 1979-97”, Journal of Public Economics, 85, 1-31. 
Brouwer, E., P. den Hertog, T. Poot, and J. Segers (2002), "WBSO nader beschouwd. Onderzoek naar de effectiviteit van de WBSO", Opdracht van het Ministerie van Economische Zaken, DG Innovatie, den Haag, Netherlands.

Bureau of Industry Economics (1993), R\&D, Innovation and Competitiveness: An Evaluation of the Research and Development Tax Concession, Research Report 50, Australian Government Publishing Service, Canberra.

Cappelen, A., A. Raknerud and M. Rybalka (2008), "The effects of R\&D tax credits on patenting and innovation”, Discussion paper 565, Statistics Norway, Oslo.

Cervantes, M. (2007), "Policies to foster R\&D and innovation in OECD countries", presentation at the Seminar on How R\&D Tax Incentives Can Boost the Competitiveness of European High Tech Industry, Stockholm,

Cornet, M. en B. Vroomen (2005), "Hoe effectief is extra fiscale stimulering van speuren ontwikkelingswerk", CPB Document 103.

Crépon, B., E. Duguet and J. Mairesse (1998), “"Research, Innovation and Productivity: An Econometric Analysis at the Firm Level", Economics of Innovation and New Technology, 7, 115-158.

Czarnitzki, D., P. Hanel and J. Rosa (2004), "Evaluating the Impact of R\&D Tax Credits on Innovation: A Microeconometric Study on Canadian Firms", ZEW Discussion Paper No. 04-77.

Dagenais, M., P. Mohnen and P. Therrien (2004), « Les firmes canadiennes répondentelles aux incitations fiscales à la recherche-développement? », Actualité Économique, $80(2 / 3), 175-206$. 
Duguet, E. (2007), "L'effet du crédit d'impôt recherche sur le financement privé de la recherche: une évaluation économétrique", mimeo.

Haegeland, T. and J. Moen (2007a), "The relationship between the Norwegian R\&D tax credit scheme and other innovation policy instruments", reports 2007/45, Statistics Norway 2007

Haegeland, T. and J. Moen (2007b), "Input additionality in the Norwegian R\&D tax credit scheme", reports 2007/47, Statistics Norway 2007

Hall, B. (1993), "R\&D tax policy during the eighties: success or failure?', Tax Policy and the Economy, 7, 1-36.

Hall, B. and J. van Reenen (2000), "How effective are fiscal incentives for R\&D? A review of the evidence", Research Policy, 29, 449-469.

Hollander, A., A. Haurie and P. L'Ecuyer (1987), "Ratched effects and the cost oof incremental incentive schemes", Journal of Economic Dynamics and Control, 11, 373389.

Jones, C. I. and J. C. Williams (2000), "Too much of a good thing? The economics of investment in R\&D”, Journal of Economic Growth, 5, 65-85.

de Jong, J.P.J. and W.H.J. Verhoeven (2007), Evaluatierapport WBSO 2001-2005: Effecten, doelgroepbereik en uitvoering. Opdracht van het Ministerie van Economische Zaken, DG Innovatie, Den Haag, Netherlands.

Lattimore, R. (1997), "Research and development fiscal incentives in Australia: Impacts and policy lessons", in Policy Evaluation in Innovation and Technology. Towards Best Practices. OECD, Paris. 
Lemaire, I. (1996), “Optimal firm response to incremental tax credits”, CREST working paper 9657 , INSEE.

Lokshin, B. and P. Mohnen (2007a), Achtergrondstudie A - Econometrische Analyse in de Jong, J.P.J. and W.H.J. Verhoeven (2007).

Lokshin, B. and P. Mohnen (2007b), "Measuring the effectiveness of R\&D tax credits in the Netherlands", UNU-MERIT working paper \#2007-025.

Mairesse J. and B. Mulkay (2004) "Une évaluation du crédit d'impôt recherche en France, 1980-1997", Revue d'Economie Politique, 114 (6), 747-778.

McFetridge, D.G. and J.P. Warda (1983), Canadian R\&D Incentives: Their Adequacy and Impact. Canadian Tax Paper No. 70, Canadian Tax Foundation, Toronto.

Nill, Jan (2005), "Design and use of fiscal incentives to promote business R\&D in CREST countries: an overview", mimeo.

Organization of Economic Cooperation and Development (2007), OECD Science, Technology and Industry: Scoreboard 2007.

Organization of Economic Cooperation and Development (2008), OECD Main Science and Technology Indicators, 2008.

Parsons, Mark and Nicolas Phillips (2007), “An evaluation of the Federal tax credit for scientific research and experimental development", Department of Finance, working paper 2007-08.

Russo, Benjamin (2004), “A cost-benefit analysis of R\&D tax incentives”, Canadian Journal of Economics, 37(2), 315-335.

Wilson, D. (2005), "Beggar thy neighbor? The in-state vs. out-of-state impact of state R\&D tax credits", Federal Reserve Bank of San Fransisco, working paper 2005-08. 